KOVALCSIK, TAMÁS

kovalcsik.tamas@geo.u-szeged.hu

PhD Student (University of Szeged, Department of Economic and Social Geography)

\author{
Nzimande, Ntombifuthi Precious
}

ntombifuthi.nzimande@geo.u-szeged.hu

PhD Student (University of Szeged, Department of Economic and Social Geography)

\title{
Theories of the voting behaviour in the context of electoral and urban geography
}

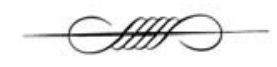

\begin{abstract}
Electoral geography - the analysing of spatial patterns in voting - intends to explore the spatialspecific factors that influence voter decisions, while the theories of voter behaviour generally seek to explain the electoral results in the individual level. In many cases, the disciplines of the electoral geography and voting behaviour analysis are connected due to their research objectives. The two subdisciplines overlap in many ways, because voter's behaviour is largely influenced by their social environment and daily interactions. This statement is especially true in a highly heterogeneous environment such as metropolitan area, where the population is vulnerable to many different influences.

Based on the above, the aim of this paper is to briefly overview the literature on electoral geography and voting behaviour, and explore its connections with spatial sciences, especially urban geography. Therefore, the first major question of the study is how electoral geography literature has developed, what topics it has focused on, and how these have evolved into voting behaviour theories. The second major question is how different theories are embedded in certain social stratifications, spatial scales and spaces, with special reference to urban areas.
\end{abstract}

\section{KEYWORDS}

Electoral geography, electoral behaviour, urban geography, urban socio-spatial processes

DOI 10.14232/belv.2019.4.15 https://doi.org/10.14232/belv.2019.4.15

Cikkre való hivatkozás / How to cite this article: Kovalcsik, Tamás - Nzimande, Ntombifuthi Precious (2019): Theories of the voting behaviour in the context of electoral and urban geography. Belvedere Meridionale vol. 31. no. 4. 207-220. pp. 
ISSN 1419-0222 (print)

ISSN 2064-5929 (online, pdf)

(Creative Commons) Nevezd meg! - Így add tovább! 4.0 (CC BY-SA 4.0)

(Creative Commons) Attribution-ShareAlike 4.0 International (CC BY-SA 4.0)

www.belvedere-meridionale.hu

\section{Introduction: Electoral Geography in Political Geography}

Electoral geography is a sub-discipline within political geography which integrates scientific results from a wide range of fields (law, political science, history, mathematics, statistics, game theory, public opinion survey, sociology, marketing, social psychology, economics) (HAJDú 2006). Its importance increased in at least two waves, first in 1945 and then in 1990, in both cases as a result of the democratization of the world and the extension of universal suffrage and electoral rights (BÉKÉSI 2004).

Its location within political geography is justified by its main objective: the spatiality of voting mechanisms. In the current democracies, the important actors who determine the geopolitical processes in their home country are chosen by the citizen of a given nation (BLACKSELL 2006). Therefore, it is important to examine the mechanism that places these actors in the geopolitical space. Furthermore, the psephology (analysis of elections) and its spatial part is intended to map the relationship between voters and politicians, through analysing public discourse. Consequently, electoral geography can provide information for various disciplines about the spatial factors that explain the decision-making mechanisms of individuals or social groups.

Based on the above, the aim of this paper is to briefly overview the literature on electoral geography and electoral behaviour, and explore its connections with spatial sciences, especially urban geography. The analysis also focuses on the origins, development, and current research direction of electoral geography, keeping focus on spatial explanations of electoral behaviour. As a conclusion of our research, we join the proposition that studying the spatiality of voter behaviour can provide primary information for the study of many other geographical phenomena.

\section{Development and Paradigms of the electoral geography}

Electoral geography has existed not only as a sub-disciplinary of science but also as a method of influencing the translation of votes into seats since Governor Elbridge Gerry in 1812, who sought to secure his power with a salamander-shaped constituency (MARTIS 2008). As a result, the most well-known term in electoral geography, gerrymandering, has been created to refer to the resultoriented bounding of constituencies. Nevertheless, the first electoral geography work had to wait for more than 100 years, when André Siegried published his work about West France in 1913, in which he discovered spatial patterns in the election results, which were associated with certain other economic, social, demographic, religious and historical spatial patterns (MEZŐ 2003). 
The first electoral works were published in England (KREHBIEL 1916), US (SAUER 1918) and Sweden (TINGSTEN 1937). While the first is a work on spatial patterns and explores their natural, economic, and social causes, the second introduced the concept of gerrymandering into the literature and discusses the manipulated constituency system of the states of Missouri, Kentucky, and Tennessee, preferring to compare electoral boundaries with ethnic maps, the third suggested the importance of the later notion "neighbourhood effect", but this work does not explicitly appear. Compared to the technical and methodological possibilities of these electoral work between 1910 and 1930, when it took weeks or months to work on an electoral map, mapping electoral results with regionalist descriptions and comparing them with already known economic or social characteristics were the maximum performance for electoral geographers of that time.

Subsequently, by the end of the 1940s, electoral geography was a positivist, descriptive and - in the spirit of the time quantitative - initially with French (not separated from electoral sociology) and later Anglo-Saxon dominance (DAVIS 1958, HAJDÚ 1992). This was further escalated in the 1950s as a result of the quantitative revolution, where social geography moved closer to traditional science. However, this was not necessarily true for the political geography. In a book review BERRY (1969) describes the political geography as a moribund backwater, because of forcing the geopolitical perception of the 1930s. In many cases, political geography has not been able to break the old, regionalist view of space as an independent container. Moreover, between the 1950s and the mid-1970s, the electoral geography did not respond most rapidly to the trends of the quantitative revolution too (BURTON 1963). This may be due to that electoral geography was already highly quantitative, so its researchers did not feel the need to improve the methodological and theoretical framework of the quantitative revolution. In addition, apart from geography, other frontier sciences have been criticized for partial discipline. According to RowLEY's (1969) critique from behavioural science and various social theories, electoral geography in many cases does not use these existing theories in its work (citing to Cox's [1968] work).

In response to the critiques, electoral geography has been the leader of reforming political geography since the mid-1970s (JOHNSTON 2001). Peter Taylor contributed to this with the issue of the difference between votes' and seats' ratios (GUDGIN-TAYLOR 1979) and defined the district bounding as a modifiable areal unit problem and proposed this into electoral geographical discourse (TAYLOR-OPENSHAW 1979). He introduced the role of the boundaries in the translation of votes into seats by breaking the container theory of the 1930s by analysing and demonstrating the effects of the boundaries themselves (TAYLOR 1973). Due to the majority electoral system of the AngloSaxon world, American and British electoral geographic work in largely focuses on the redistricting (as shown in the three examples above).

However, besides analysing constituencies, many other subjects were covered by electoral geography. According to AGNEW (1990), during the aforementioned recovery period, between 1960 and 1987, electoral geography research focused on four objectives: geography of - (1) electoral behaviour, (2) interpersonal information flow and voting behaviour, (3) electoral systems and (4) political parties. This literature review focuses on publications and research findings of the first two objectives. The last two are difficult to distinguish but their interdependencies are unquestionable. By way of the example, numerous works have already demonstrated how spatiality of voting behaviour influences the bias of the electoral systems and thus the election results (TAYLOR 1973, JOHNSTON 2002). 
The scale of the examination of voting behaviour has been constantly changing during this period. The focus was first on the state level then it crawled to the examination of everyday life in four stages. Firstly, from 1965 to 1972, Cox (1969) introduced "neighbourhood effect" into the scientific discourse, which refers to influencing the voter by his/her local social networks (JOHNSTON 1986). Because in this period there is a state controlled and "containerized" modernization view in the political geographic literature, Cox described it as electoral behaviour within national frameworks. Secondly, in the early 1970s, social problems and conflicts also came within the scope of electoral geographers (because of the disintegration of the welfare state), so they wanted to describe and relate electoral behaviour to access to public services (Cox 1973). In the third period, mid1970s, the effect of neomarxist uneven development was also observed in, for example, ARCHER-TAYLOR (1981), which attempts to explain the different electoral spatial patterns in the United States using Wallerstein's World-system theory (voting of the core and peripheral areas in different ways). The last period up to the completion of the 1990 major paper (JOHNSTON et al. 1990), micro-sociological spaces, places played an important role in AGNEW's (1985) work, emphasizing the role of the social context in the Scottish National Party support.

Due to the disintegration of the eastern bloc, electoral geography analysis in the 1990s also expanded spatially. The developed world began to be interested in the electoral process within the democracies that emerge from state-socialist systems. For example, a number of electoral geography publications from Hungary appeared in more prestigious English-language journals. Initially, only the electoral results were mapped with minimal interpretation of the spatial processes conducted (MARTIS et al. 1992, KOVÁCS 1993), and later the Hungarian spatial model of electoral behaviour was created by KovÁCS-DINGSDALE (1998), based on the LIPSET-ROKKAN (1967) cleavage theory (this will be elaborated in the next section). After the 2000s, the works were published based on the Hungarian election results on constituency-scale (MÉSZÁROS et al. 2007) and criticizing the redistricting at 2011 (KovÁCS-VIDA 2015).

One of the current three major trends in electoral geography (SHIN 2015) is still an understanding of what and how are votes influenced and whether this is at the local (neighbourhood effect) or at the higher level. This includes research on places that influence electoral outcomes, embedded contexts and scale (AGNEw 1996). The other two major trends, the mapping of election results and the geographic dimensions of the translations of votes into seats, appear in current electoral geographic work, partly separate, partly connected.

The recent electoral literature (psephology) has paramount importance where the history does not end in the state of liberal democracy, contrary to FUKUYAMA (1992), but is under constant attack by autocratic states like Russia and China. ${ }^{1}$ Although Gvosdev (2019) believes that this Russian attack - which underlie liberal democracies - is much more a geopolitical rather than an ideological interference, nonetheless, spatiality of recent electoral behaviour research should consider not only localities but also this global context. In addition, the Cambridge Analytica scandal has proven to the general public and researchers that social media is one of the most effective tools for influencing election results from abroad (REED 2015, LATERZA 2018, TERÁN-MANCERA 2019).

\footnotetext{
${ }^{1}$ IGNATIEFF, MichaEL (2014): Are the authoritarians winning? - New York Review of Books July 10. http://www.nybooks.com/ articles/archives/2014/jul/10/are-authoritarians-winning/ (downloaded: 2019. 06. 09.).
} 
According to Manuel Castells, cyberspace is a corridor between real spaces (MÉsZÁROS 2009). As part of this, social media platforms provide a unique virtual space to connect and provide information to millions or even billions of people. These platforms play an important role in examining the spatiality of voting behaviour, because they provide unprecedented data about social relationships, the evolution of public discourse, and the spread of political information. The cyberspace is a place where everything is digitally documented and stored. However, it is important to note that we get a non-representative picture of the influence of voting behaviour by analysing social media, because not all activities take place on these platforms. Despite this, in most communities and certain age groups, these platforms have become the primary source of information about political events ( $69 \%$ of Americans use social media and $30 \%$ of voters actively use Twitter [GROVER et al. 2018]).

A phenomenon of electoral geography and voting behaviour, polarization and its spatial projection has also been demonstrated using information from cyberspace. Polarization occurs when different party voters are ideologically alienated, and the number of centrists decreases (KINSELLA et al. 2015). Geographic polarization is the spatial dimension of this, when like-minded people move into a community, increasing segregation between neighbourhoods (BISHOP-CUSHING 2008). The spatial concept describes a phenomenon similar to the classic neighbourhood effect (JOHNSTON et al. 2000) but extends it somehow. The polarization of political discourse during the 2016 US presidential election was examined on Twitter (GROVER et al. 2018) and the Brexit referendum on Facebook (DEL VICARIO et al. 2017). Both studies found two separate and completely non-communicating echo chambers in social media, belonging to two different political sides and interpreting the same news in a completely different way. Using cyberspace data, CHEN-RoHLA (2018) has shown that after the 2016 presidential election, political polarization has become very high that those family members whose voting for different presidential candidates spent significantly less time on the postelection family event (Thanksgiving). For the geographic polarization, KINSELLA et al. (2019) discovered clear spatial divide between the locations of partisan voters and the policy issue voters in several major cities of US on microscale. The interesting thing about their research is that it compares the spatial results of a referendum on a cultural war issue (same-sex marriage) with party support, and there was a strong relationship between the partisan and policy issue voters. However, one of the limitations of this relationship is that there were some localities where certain voters were more likely to vote differently from partisan expectations.

Electoral geography has recently become more closely related to the connecting disciplines, which describe spatial or social phenomena, draws on quantitative spatial analysis, political economy, and postmodern space theories thus increasing the methodological and theoretical embeddedness of this sub-discipline (LEIB-QUINTON 2011). Electoral geography will never be able to detach itself from the quantitative analysis of results from its objective (election results) (LEWIS 1965), because elections provide abundant data and material on many aspects of society. However, due to the fast processing of data and the reduction of the necessary time, from the examination of social discourse, beyond the production of existing economic, cultural, and social spaces, we can observe the impact on society of the dominance of power and flexible accumulation of the capital. In doing so, electoral geography goes beyond its scope of examining voting as a manifestation of social opinion, but also analysing the discourse that it creates and the reflections on it (NICLEY 2011). 


\section{THEORIES OF THE VOTING BEHAVIOUR}

Beyond the historical and thematic overview of electoral geography, it is necessary to mention the historical changes and major paradigms of voting behaviour that are not necessarily spatial. According to the sociological theory, also called Berelson and Lazarsfeld's model (BERELSON et al. 1954), voters' decision is determined by the voter's social background, ethnicity, religion, family traditions, personality, and attitude to certain issues. Intergroup differences were also discovered based on voter behaviour between those born before and after the Great Depression. Additionally, the importance of family relationships was emphasized when a child assumed the same social status as his or her parents.

After the theory of sociology, an economic-based voting behaviour theory was born that focused on rational human choice (Downs 1957). According to this theory, voters have specific goals and they seek them most effectively through the act of voting (or not voting), so it influences them in making their decision. The relationship between the cost of voting and the likelihood of voting benefits is considered. Several critics of the theory have come to light recently, starting with the fact that if voters were to manage the benefits of voting at an individual level, nobody would vote (WILLIAMS 2011). It has also been criticized that a rational decision requires the collection of sufficient information (which is a burden on the time cost of voting), but it is not collected by those who ultimately vote, so their vote becomes irrational (POPKIN 1991).

The interdisciplinary nature of voting behaviour research is supported by the fact that after the sociology and economic theory, a psychological voting behaviour theory of party identification, came from CAMPBELL et al. (1960). Combining the aforementioned two theories, they considered the voters' attitudes to be the basis for various political organizations (because the book is American, it defines specific attitudes toward Democratic and Republican candidates, parties, foreign policy, domestic politics, and so forth.) (WILliams 2011). As a critic for the party identification model, LIPSET-ROKKAN (1967) formulated their own theory, emphasizing the importance of social cleavages. According to them, the positive or negative attitudes described in the party identification model are largely determined by the socio-economic cleavages found in the population of a certain nation. According to this, contradictions such as the place of residence (urban-rural) or the economic class one belongs to (capitalist-worker) are the greatest estimates for the voting behaviour.

In addition, according to many researchers, the mass media influences voting behaviour. The direct effect of mass media is concretized by the two step-flow hypotheses (LAZARSFELD et al. 1948). The theory is that the mass media does not send information directly to voters, but through opinion leaders. RoBINSON (1976) further elaborates on this through the impact of interpersonal networks and the introduction of a level of political awareness. His research in the 1968 presidential election in the USA showed that the more informed a voter is, the less he or she will be influenced by the mass media. If this level reaches a critically low point, the voter will receive information only from the mass media, while in other cases (which means a large majority of voters), information and ideologies will flow continuously from the more informed to the less informed voters. ZALLER (1992) joins this separation by saying that a person who actively participate in political discourses is less likely to be influenced through mass media due to their coherent basic value system. However, the superficial voter has less knowledge and thus cannot reject new information because of inconsistent value system. Thus, not only the mechanism 
of interpersonal communication but also the interpretation processes within voters have been mapped within the voting behavioural literature.

In this context, numerous studies point to links between voting behaviour and social capital (Putnam 1995, Alesina - La FerRara 2000, 2002). Although social capital was firstly mentioned by Pierre Bourdieu, who appended to his conflict and structuralist class theory beside his cultural and economic capital, in parallel Robert D. Putnam developed his own social capital, specifically derived from an analysis of the American democracy and organized around trust (SIISIÄINEN 2003, FÜZÉR 2016). PUTNAM (1995) sought to explain social capital within voting behaviour, one of its components, participation. According to him, social capital is a common knowledge created through the interaction of those within society, with the existence of it strengthening the cohesion of the society. This leads to a high voter turnout on common issues (and not only in elections). According to his surveys, social interactions and therefore social capital are decreasing, which ultimately, reduces voter participation (PUTNAM 1995, WiLliams 2011). This declining component can be linked to the aforementioned higher polarization level of the society.

\section{VOTING BEHAVIOUR IN THE URBAN CONTEXT}

Electoral geography analyses embedded in different spaces can be a special focus. This is especially true for metropolitan areas where, due to complex spatial processes, there is an extremely diverse inner structure. Therefore, if we accept any of the aforementioned theory of electoral geography or voting behaviour, the explanation of metropolitan votes is a particularly complex issue. Moreover, these spaces are most often characterized by rapid transformation in time and in physical space (such as gentrification) (BoRos et al. 2016), which also has far-reaching consequences for electoral spatial patterns. In our opinion, it is worth examining urban and electoral geographic spatial processes together in such pilot areas. Therefore, in this section we first review the literature on urban spatial structure, and then after the related electoral geography works.

The Chicago School was the first to focus on the spatial structure of the city in the 1920s under the name of urban ecology through developing three models: concentric zone (Burgess and Park) (PARK et al. 1967), sector (Hoyt) (ADAMS 2005) and the multiple nuclei (Harris and Ullman) (HARRIS-ULLMANN 1945). These models have been criticized from the very moment they were introduced due to their schematic and overly simplistic nature. The concept was that spatial structure of social processes was modelled on the tools and rules of ecology and evolution. The researchers of the Chicago School were mistaken to see the city as a spatial construct with free competition between social groups for jobs, opportunities and land, whereas these processes control the inner social spatial structure of cities (KUHLKE 2006).

Closely related (and mathematically supported) to the urban ecological models is the Alonso model of land rent, an improved version that was described by WHEATON (1974), with which the model of urban economics was created. The model predicts the population density, land cost and function at each point of the city. This prediction is calculated from the intersections of the profit and land loss curves. However, this model of mere utility and efficiency of site selection also oversimplifies the spatial structure of the city and does not address possible interests within the city and human factors. The aforesaid models are based on the organic development of society and the self-regulating system of free market processes, so the electoral geographical analysis 
based on this perception can be defined as the product of this, based on the existing conditions. Thus, the model of rational choice defined by Downs (1957) is most closely connected to this.

In contrast, Marxist-based political economy and critical geography have deduced a theoretical model of the inner structure of the city from class conflict situations based on the contradictions of capitalism (GYIMESI 2013). The critical theory explaining many spatial structures can be grouped around two major theories: class conflict and capital accumulation. According to the class conflict theory, urban spaces are designed to serve the interests of profit maximization as efficiently as possible. In this sense, the active actors are the capitalists, while the passive "sufferers" of this process are the working class. This changed when workers were able to organize themselves with the labour union, thus suppressing the intention to profit maximize of capital. Due to this, capital left the inner neighbourhoods and urban sprawl began (KUHLKE 2006). Here comes the second theoretical framework, the theory of capital accumulation, which defines the urban structure by flowing the surplus production of capital through the primary, secondary and tertiary circles to maximize profits (HARVEY 1978), inter alia with the growth coalitions (BorOs 2018). This explains several urbanization phenomena, such as the development of gentrification, suburbanisation and the appearance of gated communities.

The initial studies of urban voting behaviour are located around the spatial phenomenon of suburbanization, both in the westernized country and in Hungary (JANKÓ-KOMORNOKI 2008, VASÁRUS-VIDA 2014). Research has also been carried out in Great Britain, Canada and the US on the political identity of suburban citizens (COX 1968, WALKS 2005, 2006). On this basis, while inner-cities perform better in left-wing or social-democratic parties or candidates, traditionally right-wing parties have a higher voter support in suburban areas WALKS (2006), in his study of the Toronto metropolitan area, concluded that of the many explanations given to this polarization, the two most powerful are the effects of self-selection mechanisms and social interactions. The first one explains segregation by lifestyle choices. Based on this, there is a lifestyle closely related to the suburbs, which is much more typical of the Republicans, and there is a characteristic of inner-city neighbourhoods, which is much more typical of Democratic voters. The author states that the party identification model of CAMPBELL et al. (1960) refers in relation to the identity of voters, because the voter spontaneously chooses a place of residence appropriate to voter's own internal identity (BISHOP-CUSHING 2008). The second explanation is based on social interactions as it is strongly based on the concept of neighbourhood effect, in which it confirms the escalation of the segregation process.

The next urban phenomenon that may influence voting behaviour is gentrification. Its evolution has been studied from multiple angles, which can take on a variety of approaches from urban renewal to political economy. Starting from the uneven development, SMITH (1982) first described the theoretical model of gentrification, in which the most important phenomena were the rentgap and value-gap which means the gap between the actual capitalized ground rent or value (with the present using) and the potential rent or value (with a higher or better using) (SMITH 1987). Renewed neighbourhoods are bringing new and higher-status citizens to the area, and old citizens, who are largely under-educated and economically vulnerable, are often displaced. The effect of this process on voting behaviour was examined by the authors of KNOTTS-HASPEL (2006). In their theoretical review, they argue that some people with a low level of education who live next to a highly educated person (and are in active social interaction with them) are more likely to vote with their neighbour.

However, the claims in the literature are unclear. One theory emphasizes mobilization among old tenants, who as a result of new movers, become closer and therefore more involved in public 
debate, as well as become more active participants in political events (OLIVER 1999). However, not everyone agrees as there are those who argue that the insecurity and frustration stemming from gentrification are precisely what diminishes the confidence of voters in democratic institutions and hence their political activity. For example, research in Atlanta has shown that gentrification reduces voter turnout among both newcomers and old residents (KNOTTS-HASPEL 2006).

The appearance of gated communities also has many effects on people living in and around it (KovÁCS-HEGEDÚs 2014). The effect of gated communities on voting behaviour has also been studied by WALKS (2010). The existence of self-governing communities at some level is also a matter of political and settlement geography, but the voting manifestation of this is worth exploring in electoral geography. The main question was whether people living in a gated community behave differently from others and if they are, is it caused by people from certain social groups or the context of the place itself. To determine this, polling districts with the same demographics, real estate prices and social composition as in the gated community were used as control areas. The study concludes that people in the gated community voted more for the conservative side than for the left. At the same time, the willingness to participate was not significantly lower, but was significantly lower than that of the residents around them. This shows that self-government and partial self-administration turn off people's eyes on larger political issues (WALKS 2010).

To conclude the connection between electoral and urban geography, we would like to present articulated thoughts in a Tel Aviv case study (CHARNEY-MALKINSON 2015). With regard to the Israeli capital, the authors expressed the hope that by mapping the election results (at least every four years, but in some cases more frequently) and by understanding the underlying processes, the city geography itself can provide a good resolution and even the processes of internal transformation. Not only can electoral geography deal with the mapping of voices, but it can serve as a basis and background for urban studies that otherwise have access only to larger-scale, scaled-up information, or to highly detailed, but not representative, qualitative information.

\section{Conclusions}

In many cases, the two sub-disciplines of psephology literature, geography-based electoral geography and behavioural studies-based voting behaviour analyses, are interconnected. This is particularly true in those analyses which are embedded in different spaces and their contexts. Numerous theories have been developed to explain the spatiality and voting behaviour, which at first glance contradict each other. However, in the literature review, we have seen that some theories give stronger, and some give weaker explanations in different scales and spaces. Of course, in theories with non-space, this is true for different social groups, but it is also increasingly spatial because of the geographic polarization.

Thus, the aim of spatiality of voting behaviour analysis is dual, on the one hand, it has to explore the reasons behind the vote as a manifest political expression, and on the other hand, it may provide additional information to the various peer disciplines (urban geography, behavioural studies). By its objective of analysis, elections are the best full-sample polls, which provide information on the entire population at least every four years (even for those who did not vote, as this is a decision). However, with the advancement of cyberspace and exploration exploiting it, electoral information may seem redundant, but these information is perfectly good for validating these highly biased (non-representative) analyses. 


\section{REFERENCES}

ADAMS, JoHn S. (2005): Hoyt, H. 1939: The structure and growth of residential neighborhoods in American cities. Washington, DC: Federal Housing Administration. Progress in Human Geography vol. 29. no. 3. 321-325.

Agnew, JoHn A. (1985): Models of Spatial variation in Political Expression: The Case of the Scottish National Party. International Political Science Review vol. 6. no. 2. 171-196.

Agnew, John A. (1990): From political methodology to geographical social theory? A critical review of electoral geography, 1960-87. In Johnston, R. - Shelley, F. M. - TAYlor, P. J. (eds.): Developments in Electoral Geography. London, Routledge. 15-21.

Agnew, John A. (1996): Mapping politics: how context counts in electoral geography. Political Geography vol. 15. no. 2. 129-146.

Alesina, Alberto - La Ferrara, Eliana (2000): Participation in Heterogeneous Communities. The Quarterly Journal of Economics vol. 115. no. 3. 847-904.

Alesina, AlBerto - La Ferrara, Eliana (2002): Who trusts others? Journal of Public Economics vol. 85. no. 2. 207-234.

Archer, J. Clark - TAylor, Peter J. (1981): Section and Party: A Political Geography of American Presidential Elections, from Andrew Jackson to Ronald Reagan. Chichester, Wiley.

BÉKÉSI, LÁszló (2004): A politika földrajza. [The geography of politics] Budapest, Aula Kiadó. 161-166. Berelson, Bernard R. - Lazarsfeld, Paul F. - McPhee, William N. (1954): Voting: A study of opinion formation in a presidential campaign. Chicago, University of Chicago Press.

BERRY, BRIAN J. L. (1969): Book review: International Regions and the International System: A Study in Political Ecology. Geographical Review vol. 59. no. 3. 450-451.

Bishop, Bill - Cushing, Robert G. (2008): The Big Sort: Why the Clustering of Like-Minded America Is Tearing Us Apart. New York, Houghton Mifflin Company.

Blacksell, Mark (2006): Political Geography. New York, Routledge. 115-131.

Boros, LAJOs (2018): Growth coalitions and the control of public space. Belvedere Meridionale vol. 30. no. 4. 124-140.

Boros, Lajos - FABUla, Szabolcs - HorvÁth, DÁNIEL - KovÁCs, Zoltán (2016): Urban diversity and the production of public space in Budapest. Hungarian Geographical Bulletin (2009-) vol. 65. no. 3. 209-224.

BurTon, IAn (1963): The Quantitative Revolution and Theoretical Geography. Canadian Geographers vol. 7. no. 4. 151-162.

Campbell, Angus - Converse, Philip E. - Miller, Warren E. - Stokes, Donald E. (1960): The American Voter. Chicago, University of Chicago Press.

CHARNEY, IgAL - MALKInSON, DAN (2015): Between electoral and urban geography: Voting patterns and socio-spatial dynamics in Tel Aviv. Applied Geography vol. 58. no. 1. 1-6.

Chen, M. Keith - Rohla, Ryne (2018): The effect of partisanship and political advertising on close family ties. Science vol. 360. no. 6392. 1020-1024. 
Cox, Kevin R. (1968): Suburbia and Voting Behavior in the London Metropolitan Area. Annals of the Association of American Geographers 58. 1. 111-127.

Cox, Kevin R. (1969): The voting decision in spatial context. Progress in Geography vol. 1. no. $1.81-117$.

Cox, Kevin R. (1973): Conflict, Power, and Politics in the City: Geographic View. New York, McGraw Hill.

DAVIS, MORRIS (1958): French Electoral Sociology. The Public Opinion Quarterly vol. 22. no. 1. 35-55.

Del Vicario, Michela - Zollo, Fabiana - Caldarelli, Guido - Scala, ANTONio - QuatTrociocchi, WALter (2017): Mapping social dynamics on Facebook: The Brexit debate. Social Networks vol. 50. 6-16.

Downs, Anthony (1957): An Economic Theory of Political Action in a Democracy. Journal of Political Economy vol. 65. no. 2. 135-150.

FukuYama, Francis (1992): The End of History and the Last Man. New York, Free Press.

FÜZÉR, KATALIN (2016): The Social Theory of Trust and the Sociological Theory of Social Capital. Belvedere Meridionale vol. 28. no. 1. 132-139.

Grover, Purva - Kar, Arpan Kumar - Dwivedi, Yogesh K. - Janssen, Marijn (2019): Polarization and acculturation in US Election 2016 outcomes - Can twitter analytics predict changes in voting preferences. Technological Forecasting and Social Change vol. 145. 438-460. Gudgin, Graham - TAYLOR, PETER J. (1979): Seats, votes and the spatial organisation of elections. London, Pion.

Gvosdev, Nikolas K. (2019): Is Russia Sabotaging Democracy in the West? Orbis vol. 63. no. 3. 321-333.

GYIMESI, ZolTÁN (2013): Bevezetés: A város politikai gazdaságtana [Introduction: Political economy of the city] In JELINEK, Cs. - BodNÁR, J. - CZIRfusz, M. - GYIMESI, Z. (eds.): Kritikai városkutatás [Critical urban research] Budapest, L’Harmattan Kiadó. 39-54.

HAJdú, ZOLTÁN (1992): A választási földrajz Nyugat-Európában [The electoral geography in West-Europe] Infó-Társadalomtudomány vol. 22. no. 1. 71-75.

HAJDÚ, ZOLTÁN (2006): A 20. századi magyar parlamenti választások választási földrajzi kérdései. [Electoral Geographic Issues of the 20th century Hungarian Parliamentary Elections] Múltunk - Politikatörténet vol. 51. no. 1. 137-169.

Harris, Chauncy D. - Ullman, Edward L. (1945): The Nature of Cities. The Annals of the American Academy of Political and Social Science vol. 242. no. 1. 7-17.

HARVEY, DAVID (1978): The Urban Process Under Capitalism: A Framework for Analysis. International Journal of Urban and Regional Research vol. 2 no. 1. 101-131.

JANKÓ, FERENC - KOMORNOKI, MiHÁLY (2008): Szuburbanizáció és választási földrajz: átalakuló pártválasztás Budapest térségében [Suburbanization and Electoral Geography: Changing Party Preferences in the Area of Budapest] Tér és Társadalom vol. 22. no. 4. 115-134.

JOHNSTON, RoN J. (1986): The neighbourhood effect revisited: spatial science or political regionalism? Environment and Planning D: Society and Space vol. 4. no. 1. 41-55. 
JoHnston, Ron J. (1986): Manipulating maps and winning elections: measuring the impact of malapportionment and gerrymandering. Political Geography vol. 21. no. 1. 1-31.

JOHNSTON, Ron J. (2001): Out of the 'moribund backwater': territory and territoriality in political geography. Political Geography vol. 20. no. 6. 677-693.

Johnston, Ron J. - Pattie, Charles - Dorling, Danny - MacAllister, Iain - Tunstall, HELENA - Rossiter, DAVID (2000): The neighbourhood effect and voting in England and wales: Real or imagined? British Elections \& Parties Review vol. 10 no. 1. 47-63

Johnston, Ron J. - Shelley, Fred M. - TAYlor, Peter J. (eds.) (1990): Developments in Electoral Geography. London, Routledge.

Kinsella, Chad J. - Mctague, Colleen - Raleigh, Kevin N. (2015): Unmasking geographic polarization and clustering: A micro-scalar analysis of partisan voting behavior. Applied Geography vol. 62. 404-419.

Kinsella, Chad J. - McTague, Colleen - Raleigh, Kevin N. (2019): Geographic Polarization, Partisan Voting, and the Battle over Same-sex Marriage within the Culture War. Geographical Review vol. 109. no. 2. 224-248.

Knotts, H. GibBs - Haspel, Moshe (2006): The Impact of Gentrification on Voter Turnout. Social Science Quarterly vol. 87. no. 1. 110-121.

KovÁCS, ZOLTÁN (1993): The geography of Hungarian parliamentary elections 1990. In O'LoughLIN, J. - Wusten, H. vAN DER (eds.): The New Political Geography of Eastern Europe. London, Belhaven Press. 255-273.

KovÁcs, ZoltÁn - Dingsdale, Alan (1998): Whither East-European democracies? The geography of the 1994 Hungarian parlamentary election. Political Geography vol. 17. no. 4. 437-458.

KovÁcs, Zoltán - Hegedús, GÁBOR (2014): Gated communities as new forms of segregation in post-socialist Budapest. Cities vol. 36. no. 1. 200-209.

KOVÁCS, ZOLTÁN - VIDA, GYÖRGY (2015): Geography of the new electoral system and changing voting patterns in Hungary. Acta Geobalcanica vol. 1. no. 2. 55-64.

KREHBIEL, EdWARD (1916): Geographic Influences in British Elections. Geographical Review vol. 2. no. 6. 419-432.

Kuhlek, Olaf (2006): Urban Spatial Structure. In Warf, B. (ed.): Encyclopedia of Human Geography. Thousand Oaks - London - New Delhi, SAGE Publications. 525-527.

LAterza, Vito (2018): Cambridge Analytica, independent research and the national interest. Anthropology Today vol. 34. no. 3. 1-2.

Lazarsfeld, Paul F. - Berelson, Bernard - Gaudet, Hazel (1948): The People's Choice: How the Voter Makes Up His Mind in a Presicential Campaign. New York, Columbia University Press. LeiB, Jonathan - Quinton, Nicholas (2011): On the Shores of the "Moribund Backwater"?: Trends in Electoral Geography Research Since 1990. In WARF, B. - LEIB, J. (eds.): Revitalizing Electoral Geography. Burlington, Ashgate Publishing Company. 9-30. 
LEWIS, PEIRCE F. (1965): Impact of Negro migration of electoral geography of Flint, Michigan, 1932-1962: a cartographic analysis. Annals of the Association of American Geographers vol. 55. no. 1. 1-25.

Lipset, Seymour Martin - RokKan, Stein (1967): Party Systems and Voter Alignments: Cross national perspectives. New York, The free Press.

Martis, KenNeth C. (2008): The original gerrymander. Political Geography vol. 27. no. 1. 833-839.

Martis, Kenneth C. - Kovács, Zoltán - KovÁcs, Dezső - Péter, SÁndor (1992): The Geography of the 1990 Hungarian Parliamentary Elections. Political Geography vol. 11. no. 3. 283-305.

MÉSZÁros, JózSEF - SOLYMOSI, NORBERT - SPEISER, FERENC (2007): Spatial distribution of political parties in Hungary 1990-2006. Political Geography vol. 26. no. 7. 804-823.

MÉSZÁROS, REZSŐ (2009): A kibertér társadalomföldrajza [Social geography of Cyberspace]. Munkabeszámoló. OTKA.

MEZŐ, FERENC (2003): A politikai földrajz alapjai. [The key findings of political geography] Debrecen, Kossuth Egyetemi Kiadó. 163-192.

Nicley, Erinn P. (2011): Elections and Cultural Political Economy: The Political Geography of the Bloque Nacionalista Galego in the Galicia Autonomous Community. In WARF, B. - LEIB, J. (eds.): Revitalizing Electoral Geography. Burlington, Ashgate Publishing Company. 75-96.

Oliver, J. Eric (1999): The Effects of Metropolitan Economic Segregation on Local Civic Participation. American Journal of Political Science vol. 43. no. 1. 186-212.

Park, Robert E. - Burgess, Ernest W. - McKenzie, Roderick D. (1967): The City. Chicago, University of Chicago Press.

Popkin, SAmuel L. (1991): The Reasoning Voter: Communication and Persuasion in Presidential Campaigns. Chicago, University of Chicago Press.

Putnam, RoBert DAVID (1995): Bowling alone: America's declining social capital. Journal of Democracy vol. 6. no. 1. 65-78.

REED, MARKuM (2015): Social network influence on consistent choice. The Journal of Choice Modelling vol. 17. 28-38.

ROBINSON, JOHN P. (1976): Interpersonal Influence in Election Campaigns: Two Step-Flow Hypotheses. The Public Opinion Quarterly vol. 40. no. 3. 304-319.

Rowley, GWYN (1969): Electoral Behavior and Electoral Behaviour: A Note on Certain Recent Developments in Electoral Geography. The Professional Geographer vol. 21. no. 6. 398-400.

SAUER, CARL (1918): Geography and the Gerrymander. The American Political Science Review vol. 12. no. 3. 403-426.

Shin, Michael (2015): Electoral Geography in the Twenty-First Century In Agnew, J. A. Mamadouh, V. - Secor, A. J. - Sharp, J. (eds.): The Wiley Blackwell Companion to Political Geography. Hoboken, Wiley. 279-296.

SiISIÄINEN, MARTTI (2003): Two concepts of social capital: Bourdieu vs. Putnam. International journal of contemporary sociology vol. 40 no. 2. 183-204. 
Smith, NeIL (1982): Gentrification and Uneven Development. Economic Geography vol. 58. no. 2. 139-155.

Smith, NeIL (1987): Gentrification and the Rent Gap. Annals of the Association of American Geographers vol. 77. no. 3. 462-465.

TAYlor, Peter J. (1973): Some implications of spatial organization of elections Transactions of the Institute of British Geographers no. 60. 121-136.

TAYLOR, PETER J. - OPENSHAW, STAN (1979): A million or so correlation coefficients: three experiments on the modifiable areal unit problem. In WrigLEY, N. (ed.): Statistical applications in the spatial sciences. London, Pion. 127-144.

TERÁN, LUIS - MANCERA, JOSÉ (2019): Dynamic profiles using sentiment analysis and twitter data for voting advice applications. Government Information Quarterly vol. 36. no. 3. 520-535.

Tingsten, Herbert (1937): Political Behavior; Studies in Election Statistics. London, P. S. King and Son. VASÁRUS, GÁBOR - IDA, GYÖRGY (2014): A szuburbanizáció néhány választásföldrajzi sajátossága a győri agglomeráció és a szegedi településegyüttes példáján [Some Implications of Electoral Geographical Patterns of Suburbanization in the Agglomeration of Győr and Szeged]. Településföldrajzi Tanulmányok vol. 3. no.2. 59-72.

Walks, R. Alan (2005): City-suburban electoral polarisation in Great Britain, 1950-2001. Transactions of the Institute of British Geographers vol. 30. no. 4. 500-517.

Walks, R. Alan (2006): The Causes of City-Suburban Political Polarization? A Canadian Case Study. Annals of the Association of American Geographers vol. 96. no. 2. 390-414.

WALKS, R. ALAN (2010): Electoral behaviour behind the gates: partisanship and political participation among Canadian gated community residents. Area vol. 42. no. 1. 7-24.

WeAtherford, M. STEPHEN (1982): Interpersonal Networks and Political Behavior. American Journal of Political Science vol 26. no. 1. 117-143.

WheAton, WiLliam C. (1974): A comparative static analysis of urban spatial structure. Journal of Economic Theory vol. 9. no. 2. 223-237.

Williams, Christopher J. (2011): Voting behavior. In IshiYama, J. T. - Breuning, M. (eds.): 21st Century Political Science: A Reference Handbook. California, SAGE. 813-821.

ZaLler, John R. (1992): The Nature and Origins of Mass Opinion. New York, Cambridge University Press.

\section{ACKNOWLEDGEMENTS}

Supported by the ÚNKP-19-3-SZTE-162 New National Excellence Program of the Ministry for Innovation and Technology. 